\title{
ANALISIS UNSUR Fe, Ca, Ti, Ba, Ce, Zr DAN La DALAM SEDIMEN LAUT DI SEMENANJUNG MURIA DENGAN METODE XRF
}

\author{
Sukirno, Sri Murniasih \\ Pusat Teknologi Akselerator dan Proses Bahan
}

\begin{abstract}
ABSTRAK
ANALISIS UNSUR Fe, Ca, Ti, Ba, Ce, Zr DAN La DALAM SEDIMEN LAUT DI SEMENANJUNG MURIA DENGAN METODE XRF. Telah dilakukan analisis unsur-unsur ( $\mathrm{Fe}, \mathrm{Ca}, \mathrm{Ti}, \mathrm{Ba}, \mathrm{Ce}, \mathrm{Zr}$ dan $\mathrm{La}$ ) dalam cuplikan lingkungan sedimen laut di semenanjung Muria dengan menggunakan metode spektrometer pendar sinar-X (XRF). Tujuan penelitian untuk mengetahui sebaran unsur-unsur yang mengakomodasikan data lingkungan terkini dalam rangka mendukung ijin tapak dan Analisis Mengenai Dampak Lingkungan (AMDAL) Pusat Listrik Tenaga Nuklir (PLTN). Pengambilan cuplikan, preparasi maupun analisisnya mengacu pada prosedur analisis cuplikan lingkungan. Dari hasil analisis diperoleh unsur mayor yang terkandung dalam sedimen untuk ke 7 lokasi sampling sedimen laut adalah $\mathrm{Ca}$, Ti dan Fe dengan konsentrasi berturut-turut adalah (6,74 - 11,69) \%; (0,74 - 6,89) \% dan (0,45 -1,94) $\%$; sedangkan untuk unsur-unsur minor terdiri dari unsur $\mathrm{Ba}, \mathrm{Ce}, \mathrm{Zr}$ dan La dengan konsentrasi berturut-turut adalah $(451,4$ - 1331,6 ) mg/kg; $(201,8$ - 427,3) mg/kg; (192,3 - 338,5) mg/kg dan (171,7 - 298,4) mg/kg. Hasil uji statistik menunjukkan bahwa lokasi sampling terpengaruh nyata terhadap konsentrasi untuk semua unsur, pada pengujian dengan taraf kepercayaan 95
\end{abstract}

Kata kunci: Unsur, XRF, Muria, sedimen

\section{ABSTRACT}

ANALYSIS OF Fe, Ca, Ti, Ba, Ce, Zr AND La ELEMENT IN THE SEA SEDIMENT AT MURIA PENINSULA BY XRF METHOD. The analysis of metals ( $\mathrm{Fe}, \mathrm{Ca}, \mathrm{Ti}, \mathrm{Ba}, \mathrm{Ce}, \mathrm{Zr}$ and $\mathrm{La}$ ) in the sea sediment environmental samples at Muria peninsula has been carried out with X-Ray Fluorescence (XRF) method. The aim of this analysis is to know the distribution metals which accommodate the recent environmental data in supporting the license of site and Environmental Impact Assessment (EIA) for the Nuclear Power Plans (NPP). Sampels taken preparation and analysis based on the procedures of environmental analysis. The result analysis that contents of mayor elements in 7 sea sediment location of sampling were $\mathrm{Ca}$, Ti and Fe with concentration are $(6.74-11.69) \%$; $(0.74-6.89) \%$ and (0.45 -1.94) \% successively; while minor elements were $\mathrm{Ba}, \mathrm{Ce}, \mathrm{Zr}$ and La with concentration are 451.4 1331.6 ) $\mathrm{mg} / \mathrm{kg}$; (201.8 - 427.3) mg/kg; (192.3 - 338.5) mg/kg dan (171.7 - 298.4) mg/kg. The statistic test result shows that sampling location there is a significant difference all of element with the level significant of $95 \%$.

Keyword : element, XRF, Muria, sediment

\section{PENDAHULUAN}

Dada pertengahan tahun 2006 Pusat Listrik Tenaga Uap (PLTU) Batubara Tanjung Jati B Semenanjung Muria telah beroperasi, dan sejalan dengan itu pemerintah berencana membangun Pusat Listrik Tenaga Nuklir (PLTN) pertama di Indonesia. Terhadap kawasan calon lokasi PLTN diperlukan pemantauan yang berkesinambungan khususnya untuk memperoleh base line radioekologi, logam berat dan beracun ${ }^{(1,2)}$, sehingga sedini mungkin dapat diamati terjadinya polusi lingkungan pada waktu sekarang dan yang akan datang di sekitar daerah tersebut.

Berdasar SK Kepala Bapeten No.03-P/Ka-BAPETEN/VI- $90^{(3)}$ tentang pedoman teknis penyusunan AMDAL untuk rencana pembangunan dan pengoperasian reaktor nuklir dan SK Kepala Bapeten No 04-P/Ka-BAPETEN/ $\mathrm{VI}-90^{(4)}$ tentang pedoman teknis penyusunan analisis dampak lingkungan untuk rencana pembangunan pengoperasian instalasi lainnya. Maka dalam upaya pengelolaan lingkungan (UKL) dan upaya pemantauan lingkungan (UPL) untuk rencana usaha atau kegiatan di bidang nuklir diperlukan pengambilan cuplikan lingkungan untuk memonitoring kondisi lingkungan di sekitarnya. Pembangunan PLTN diperkirakan mempunyai dampak penting terhadap lingkungan, karena itu wajib dilengkapi dengan analisis mengenai dampak lingkungan. Begitu pula dengan rencana pembangunan PLTN, terhadap lokasi yang direncanakan harus dilakukan UKL dan 
Kajian unsur Fe, Ca, Ti, Ba, Ce, Zr dan La dalam sedimen laut di Semenanjung Muria dengan metode XRF.

UPL terlebih dahulu. Salah satu komponen dari komponen lingkungan fisikokimia yang dipilih untuk ditelaah adalah radioaktivitas.

Pesisir merupakan daerah pertemuan antara darat dan laut, ke arah darat wilayah pesisir meliputi bagian daratan baik kering maupun terendam air yang masih dipengaruhi oleh sifat-sifat laut seperti pasang surut , angin laut dan perembesan air laut, sedangkan ke arah laut, wilayah pesisir mencakup bagian laut yang masih dipengaruhi oleh proses alami yang terjadi di darat seperti sedimentasi atau pencemaran. Sesuai dengan batasan di atas sangat jelas bahwa perairan wilayah pesisir merupakan tempat pembuangan terakhir dari berbagai jenis limbah dari daratan, oleh karena itu sangat rentan mengalami pencemaran.

Polutan dalam air akan diserap oleh organisme akuatik seperti sedimen, ikan dan beberapa jenis tanaman laut yang hidup di atasnya ${ }^{(1)}$. Polutan yang masuk ke pesisir akan berinteraksi dengan salah satu media lingkungan dalam bentuk senyawa terlarut, padatan atau gas dan dapat berpindah tempat. Media tersebut dapat berupa sedimen, air dan tanaman. Akumulasi polutan dalam jaringan suatu organisme dapat menimbulkan keracunan baik dalam waktu singkat maupun dalam jangka waktu yang panjang.

Spektrometri pendar sinar- $X$ adalah cara analisis terhadap cuplikan berdasarkan pengukuran tenaga dan intensitas sinar-X suatu unsur di dalam cuplikan hasil eksitasi sumber radioisotop ${ }^{(5,6)}$. Tenaga sinar-X cuplikan yang terukur dipakai sebagai dasar analisis kuantitatif.

Pada dasarnya prinsip kerja dari spektrometer pendar sinar- $X$ adalah sinar $\mathrm{x}$ primer yang berasal dari sumber pengeksitasi ditembakkan terhadap cuplikan. Pancaran radiasi sinar $\mathrm{x}$ tersebut akan berinteraksi dengan cuplikan dalam proses efek fotolistrik. Proses interaksi tersebut akan menghasilkan pendaran sinar $x$ sekunder dari cuplikan, yang ditangkap oleh detektor kemudian dianalisis. Bila energi sinar tersebut lebih tinggi dari energi ikatan elektron dalam kulit $\mathrm{K}, \mathrm{L}$ atau $\mathrm{M}$ dari atom target maka akan menyebabkan elektron tersebut keluar dari orbitnya sehingga terjadi kekosongan elektron. Kekosongan elektron ini kemudian diisi oleh elektron dari orbital yang lebih luar dengan diikuti adanya pelepasan energi yang berupa sinar- $X$. Sinar- $X$ ini mempunyai spektrum sinambung dan spektrum berenergi tertentu sesuai dengan perpindahan elektron yang terjadi dalam atom yang bersangkutan ${ }^{(5)}$.

Pengujian unjuk kerja hasil analisis metode pendar sinar-X, (XRF) ditinjau dari akurasi hasil analisis uji. Kualitas data analitik ditentukan oleh kualitas kinerja laboratorium analitik dan bergantung banyak variabel operasional, misalnya jenis dan kondisi prasarana dan sarana, kalibrasi dan standarisasi peralatan, validasi metode, kondisi operasional dan pengalaman serta keterampilan para analisis dan supervisor. Pada dasarnya akurasi hasil analisis diuji dengan memperbandingkan terhadap cuplikan acuan standar (standard reference material, SRM).

Tujuan penelitian ini dilakukan untuk mengetahui sebaran unsur-unsur ( $\mathrm{Fe}, \mathrm{Ca}, \mathrm{Ti}, \mathrm{Ba}, \mathrm{Ce}, \mathrm{Zr}$ dan $\mathrm{La}$ ) yang terdapat dalam cuplikan sedimen laut dan pesisir semenanjung Muria yang mengakomodasikan data lingkungan terkini dalam rangka mendukung ijin tapak dan Analisis Mengenai Dampak Lingkungan (AMDAL) Pusat Listrik Tenaga nuklir (PLTN), mengingat unsur-unsur tersebut merupakan unsur-unsur yang banyak terdapat di sedimen dan apabila keberadaannya melebihi ambang batas dapat menggangu keseimbangan ekosistem lingkungan. Disamping analisis unsur dengan metode XRF, dilakukan keandalan alat dengan melakukan uji akurasi dan uji statistik Anava model desain acak lengkap dengan derajat kepercayaan $95 \%$.

\section{TATA KERJA}

Sedimen yang diambil dari Semenanjung Muria yang terletak di tepi utara pulau Jawa, wilayah kabupaten Jepara. Sampel diambil pada tanggal 22 dan 23 April 2007, dari 7 lokasi, yaitu : pesisir Beringin, Beji, Gondang, Lemahabang, Bayuran, Pantai Lemahabang, dan Muara Bayuran (Gambar 3).

\section{Alat}

Dregger (alat pengambil sedimen laut), ayakan 100 mesh, neraca Ohaus 410 GT, plastik klip, nampan plastik, lumpang tahan karat, wadah pencacahan, Spex X-Ray Cell Film, Seperangkat XRF dengan Detektor $\mathrm{Si}(\mathrm{Li})$. 


\section{Bahan}

Cuplikan sedimen sungai dari semenanjung Muria, serbuk $\mathrm{Al}_{2} \mathrm{O}_{3}$ sebagai matrik pengencer standar sekunder unsur $\mathrm{Ba}, \mathrm{Ca}, \mathrm{Ce}, \mathrm{Fe}$, La, Ti, dan Zr dengan berbagai konsentrasi dan SRM 2704 river sediment.

\section{Cara Kerja}

1. Sedimen basah diangin-anginkan sampai kering, dibuang kotorannya dan ditumbuk sampai berukuran lolos 100 mesh. Pembuatan deret standar sekunder $\mathrm{Ba}, \mathrm{Ca}, \mathrm{Ce}, \mathrm{Fe}, \mathrm{La}, \mathrm{Ti}$, dan $\mathrm{Zr}$ dengan berbagai konsentrasi dalam media matrik $\mathrm{Al}_{2} \mathrm{O}_{3}$. Standar tersebut ditimbang seberat 4 gram dalam vial pencacah dengan konsentrasi yang bervariasi, begitu pula dengan standar primer (SRM 2704 river sediment) dan cuplikan sedimen akan ditentukan konsentrasi unsur yang terdapat di dalamnya.

2. Pencacahan dilakukan untuk semua cuplikan selama 1000 detik dengan alat spektrometer pendar sinar$X$ dengan detektor Si(Li) dan MCA Ortec 7010, sumber eksitasi Am-241 dan Fe-55.

3. Metode pengukuran dilakukan secara relatif atau metode standar kalibrasi yang umum digunakan dalam kimia analitik. Konsentrasi unsur yang ditentukan diukur dengan suatu cuplikan dari deret. Laju cacah ditentukan dengan menggunakan harga intersept dari kurva intensitas net Compton $(Y)$ versus konsentrasi $(X)$, merupakan garis lurus persamaan dan perhitungan konsentrasi dalam sedimen seperti yang telah dilakukan oleh SUKIRNO $\mathrm{dk}^{[7]}$.

4. Pada dasarnya akurasi hasil analisis diuji dengan membandingkan terhadap cuplikan acuan standar (standard reference material, SRM). Perhitungan akurasi dengan menggunakan persamaan (1).

Akurasi $\left.=\left\{1-\left(\mathrm{K}_{\mathrm{S}}-\mathrm{K}_{\mathrm{U}}\right) / \mathrm{K}_{\mathrm{S}}\right)\right\} \times 100$

$\mathrm{K}_{\mathrm{S}}=$ konsentrasi unsur tercantum sertifikat

$\mathrm{K}_{\mathrm{c}}=$ konsentrasi unsur tercantum terukur

\section{HASIL DAN PEMBAHASAN}

Hasil analisis unsur dalam sedimen laut dimasukkan ke dalam dua kelompok yaitu kelompok unsur minor dan mayor. Menurut DAY dan UNDERWOOD ${ }^{[8]}$ unsur minor merupakan konstituen kecil dalam suatu sampel yaitu jika konsentrasinya kurang dari $1 \%$, pada penelitian ini yang dianggap sebagai unsur minor adalah barium $(\mathrm{Ba})$, zirkonium $(\mathrm{Zr})$, lantanium $(\mathrm{La})$ dan serium $(\mathrm{Ce})$. Unsur mayor merupakan konstituen utama yaitu konsentrasinya lebih dari $1 \%$, yang termasuk unsur mayor dalam penelitian ini adalah besi $(\mathrm{Fe})$, kalsium (Ca) dan titanium (Ti).

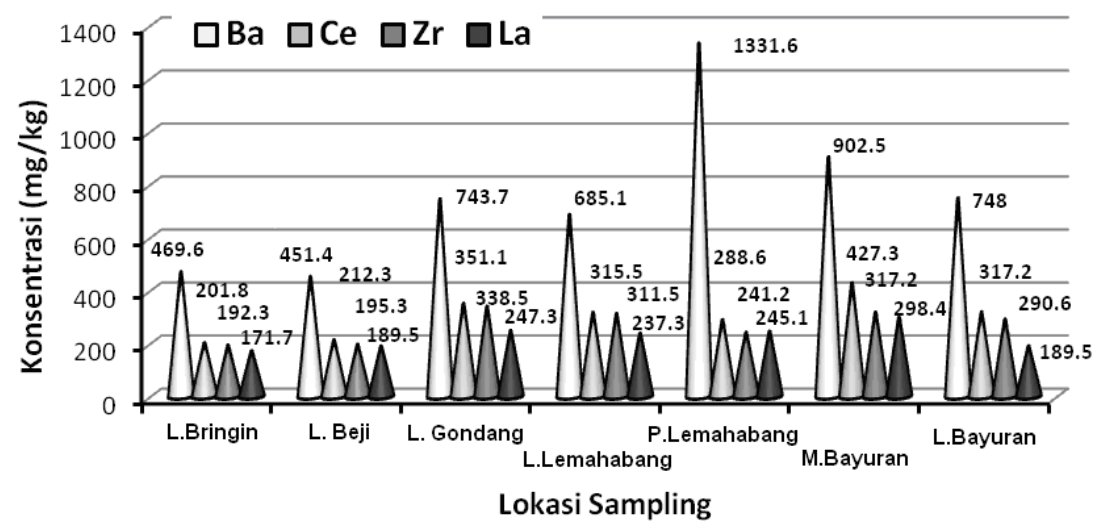

Gambar 1: Histogram konsentrasi logam minor ( $\mathrm{Ba}, \mathrm{Ce}, \mathrm{Zr}$ dan La) dalam sedimen laut

Hasil analisis unsur dalam sedimen laut untuk unsur minor dapat dilihat pada Gambar 1, sedangkan untuk unsur mayor $\mathrm{Fe}, \mathrm{Ca}$ dan $\mathrm{Ti}$ dapat dilihat pada Gambar 2, walaupun Ti mempunyai konsentrasi di bawah 1\%, hal ini dapat dikelompokkan ke dalam unsur mayor karena konsentrasi mendekati $1 \%$. Perbandingan histogram pada Gambar 1 dapat terlihat bahwa lokasi pantai Lemahabang, unsur minor Ba mempunyai perbandingan histogram konsentrasi paling tinggi berkisar antara $(451,4-1331,6) \mathrm{mg} / \mathrm{kg}$, sedangkan perbandingan histogram 
Kajian unsur Fe, Ca, Ti, Ba, Ce, Zr dan La dalam sedimen laut di Semenanjung Muria dengan metode XRF.

terkecil konsentrasinya adalah unsur La di tujuh lokasi sampling dengan kisaran nilai konsentrasi antara (171,7 298,4) mg/kg. Sedangkan untuk unsur Ce dan Zr mempunyai konsentrasi masing-masing berkisar antara (192,3 - 423,3) mg/kg dan $(192,3$ - 338,5) mg/kg. Keberadaan unsur-unsur tersebut dalam sedimen laut dapat berasal dari sumber-sumber alamiah dan sari aktivitas manusia. Sumber-sumber unsur alamiah sudah ada sejak terbentuknya sedimen dan yang masuk ke dalam ke laut bisa dari pengikisan batu mineral yang banyak terdapat pesisir maupun bawaan arus yang mengalir melalui sungai di sekitarnya.

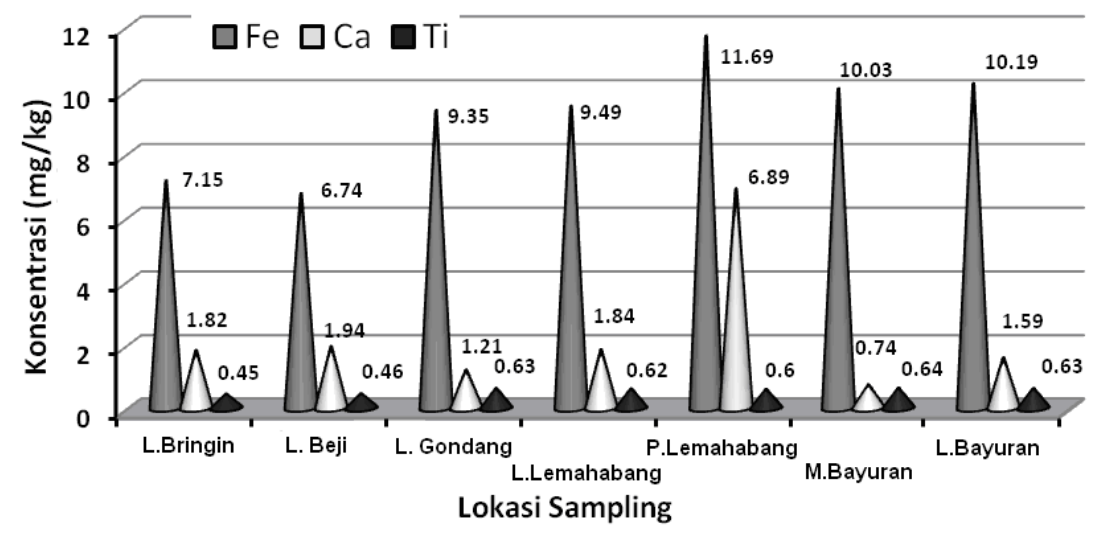

Gambar 2: Histogram konsentrasi logam mayor ( $\mathrm{Ca}, \mathrm{Fe}, \mathrm{Ti})$ dalam sedimen laut

Gambar 2 merupakan fluktuasi konsentrasi hasil analisis unsur dalam sedimen di tujuh lokasi sampling untuk unsur mayor yaitu unsur $\mathrm{Ca}, \mathrm{Ti}$ dan $\mathrm{Fe}$. Konsentrasi $\mathrm{Fe}$ dalam sedimen tertinggi dapat dilihat pada perbandingan histogram dengan konsentrasi unsur Fe $(6,74-11,69) \%$, hal ini disebabkan Fe merupakan salah satu komponen utama dalam sedimen laut, dan pada umumnya konsentrasi di pantai lebih tinggi dibandingkan di tengah laut. Kalsium $(\mathrm{Ca})$ merupakan salah satu komponen yang terdapat dalam sedimen laut dengan konsentrasi berkisar antara $(0,74-6,89) \%$. Kalsium yang terdapat pada umumnya berbentuk kalsium karbonat terbentuk dari kerangka organisme laut yang tak terhitung jumlahnya. Unsur Ti terdapat di banyak mineral dengan sumber utama adalah ilmenite dan rutile bersama-sama dengan unsur Fe tersebar luas di seluruh bumi, sehingga Ti merupakan komponen utama dalam sedimen. Kandungan unsur Ti yang teranalisis mempunyai konsentrasi berkisar $(0,45-0,64) \%$.

Tujuan utama yang harus dicapai oleh suatu laboratorium pengujian adalah menghasilkan data uji yang valid, secara sederhana hasil uji yang valid dapat digambarkan sebagai hasil uji yang mempunyai akurasi dan presisi yang baik. Metode uji memegang peranan yang sangat penting dalam memperoleh hasil uji dengan akurasi dan presisi yang baik. Pada penelitian ini standar reference material (SRM) yang digunakan adalah Buffalo River Sediment 2704, hasil perhitungan disajikan pada Tabel 1. Pencacahan untuk pengujian dilakukan dengan tujuh kali pengulangan, hasil dari akurasi disajikan pada Tabel 1. Hasil pengujian akurasi pada umumnya dikatakan paling baik apabila nilai biasnya mendekati nilai nol atau akurasinya mendekati nilai $100 \%$. Semakin dekat konsentrasi unsur yang dianalisis dengan konsentrasi unsur yang tercantum dalam sertifikat berarti penggunaan metode XRF untuk menganalisis unsur semakin baik. Hasil nilai akurasi pada penelitian ini lebih besar $85 \%$ dapat dikatakan cukup baik dan dapat dipertanggungjawabkan untuk analisis unsur minor dan mayor.

Besarnya nilai penyimpangan data hasil uji ketujuh unsur diperoleh bahwa unsur $\mathrm{Ba}$ mempunyai penyimpangan terbesar, konsentrasi Ba dalam sertifikat $414 \pm 12 \mathrm{mg} / \mathrm{kg}$ sedangkan yang terukur konsentrasinya $356,3 \pm 3,9 \mathrm{mg} / \mathrm{kg}$ sehingga hasil akurasi yang dihitung menggunakan persamaan (1) mempunyai nilai $86,69 \%$. Unsur Ce mempunyai nilai bias kecil $(2,09 \%)$ dan mempunyai nilai akurasi tertinggi dibandingkan unsur-unsur lainya yaitu sebesar $97,91 \%$. 
Kajian unsur Fe, Ca, Ti, Ba, Ce, Zr dan La dalam sedimen laut di Semenanjung Muria dengan metode XRF

Tabel 1. Hasil perhitungan akurasi menggunakan standar reference material (SRM) yaitu Buffalo River Sediment 2704

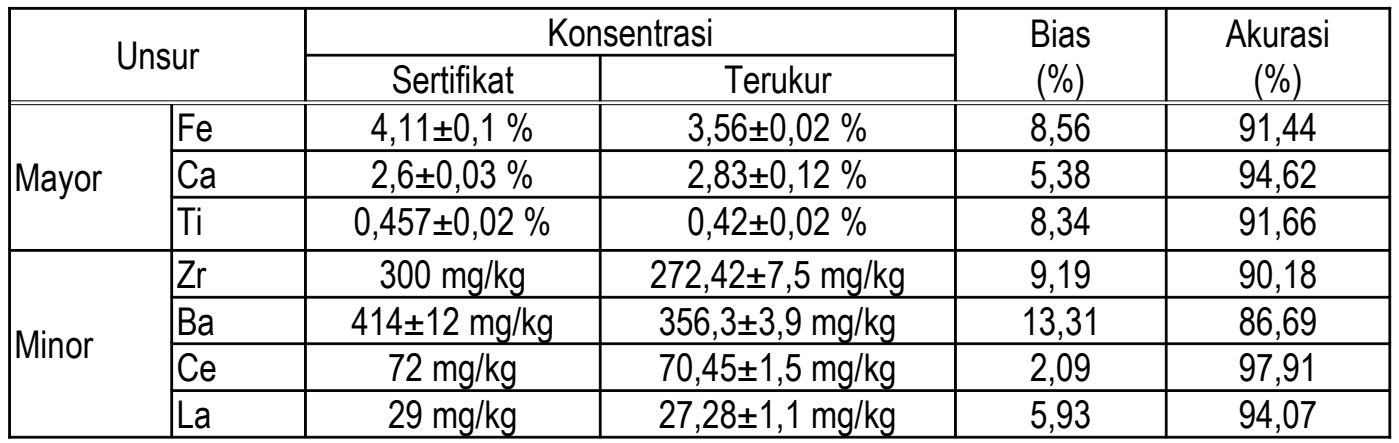

Untuk mengetahui pengaruh lokasi sampling terhadap konsentrasi unsur dilakukan uji statistik menggunakan metode analisis varian (ANAVA) model desain acak sempurna, persaman yang digunakan seperti yang telah diuraikan oleh SUDJANA ${ }^{[9]}$. Dengan menggunakan bantuan program Excel, data yang ada dapat dihitung dengan benar sehingga diperoleh hasil uji statistik ANAVA seperti yang terdapat pada data perbandingan histrogram Gambar 1 dan 2. Berdasar data tersebut maka dapat diketahui perbedaan kandungan unsur dalam sedimen.

Nilai kandungan unsur Fe dalam sedimen dari tujuh lokasi sampling dilakukan uji $F$. Pada perhitungan uji $F$ diambil taraf nyata $(\alpha=0,05)$, distribusi $F_{\text {tabel }}=2,85$ sedangkan distribusi $F_{\text {hitung }}=49,41$ hal ini menunjukkan bahwa $F_{\text {tabel }}<F_{\text {hitung }}$ yang berarti lokasi sampling untuk unsur $F e$ ada beda secara nyata. Bila lokasi sampling Bringin, Beji dan pantai Lemahabang tidak disertakan maka nilai distribusi $F_{\text {hitung }}=2,14$ dan nilai distribusi $F_{\text {tabel }}=$ 4,76, sehingga ada 4 lokasi (Gondang, Lemahabang, Bayuran dan muara Bayuran) konsentrasi unsur Fe dinyatakan tidak ada beda secara nyata.

Tabel 2. Distribusi $F$ dengan taraf nyata $(\alpha=0,05)$ untuk sedimen laut dengan tingkat kepercayaan $95 \%$.

\begin{tabular}{|c|c|c|c|c|}
\hline \multirow{2}{*}{ Unsur } & \multicolumn{2}{|r|}{ Perlakuan Lokasi } & \multicolumn{2}{|c|}{ Distribusi F } \\
\hline & Jumlah lokasi & Kecuali & Hitung & Tabel \\
\hline \multirow{2}{*}{$\mathrm{Fe}$} & 7 & - & 49,41 & 2,85 \\
\hline & 4 & Bringin, Beji, P.Lemahabang & 2,14 & 4,76 \\
\hline \multirow{2}{*}{$\mathrm{Ti}$} & 7 & - & 7,06 & 2,85 \\
\hline & 5 & Bringin, Beji & 0,29 & 3,48 \\
\hline \multirow{2}{*}{$\mathrm{Ca}$} & 7 & - & 10,31 & 2,85 \\
\hline & 3 & M.Bayuran, Gondang, P.Lemahabang, Beji & 1,30 & 5,14 \\
\hline \multirow{2}{*}{ La } & 7 & - & 9,08 & 2,85 \\
\hline & 5 & Bringin, M.Bayuran & 325 & 348 \\
\hline \multirow{3}{*}{$\mathrm{Ce}$} & 7 & - & 168,5 & 2,85 \\
\hline & 2 (Bringin, Beji) & & 1,48 & 7,71 \\
\hline & 2 (Bayuran, L.LA) & & 0,01 & 7,71 \\
\hline \multirow{2}{*}{$\mathrm{Ba}$} & 7 & - & 815,20 & 2,85 \\
\hline & 2 (Gondang, Bayuran) & & 0,07 & 7,71 \\
\hline \multirow{2}{*}{$\mathrm{Zr}$} & 7 & - & 37,14 & 2,85 \\
\hline & 3 & Bringin, M Bayuran, P.Lemahabang, Beji & 2,55 & 5,14 \\
\hline
\end{tabular}

Untuk unsur Ti dilihat dari distribiusi $F\left(F_{\text {hitung }}<F_{\text {tabel }}\right)$ konsentrasi yang terhitung tidak beda secara nyata kecuali pada lokasi Bringin dan Beji, begitu juga unsur La dimana distribiusi $F\left(F_{\text {hitung }}<F_{\text {tabei }}\right)$ kecuali pada lokasi Bringin dan muara Bayuran. Dari keseluruhan unsur dan lokasi sampling pada Tabel 2 dapat diketahui bahwa konsentrasi unsur $\mathrm{Ti}, \mathrm{Ca}, \mathrm{Fe}, \mathrm{Zr}$, Ba, La dan $\mathrm{Ce}$ tidak berpengaruh terhadap perbedaan lokasi kecuali unsur $\mathrm{Ca}$ dan Ti. 
Kajian unsur Fe, Ca, Ti, Ba, Ce, Zr dan La dalam sedimen laut di Semenanjung Muria dengan metode XRF.

Untuk lokasi sampling sedimen laut keseluruhan hasil $F_{\text {hitung }}$ dan distribusi $F_{\text {tabel }}$ dapat dilihat pada Tabel 2 terlihat bahwa konsentrasi unsur Fe dan La tidak ada beda secara nyata terhadap perbedaan lokasi sampling, hal ini disebabkan nilai distribusi $F_{\text {hitung }}$ lebih kecil daripada distribusi $F_{\text {tabel. }}$. Konsentrasi unsur Ba dan Sr tidak ada beda secara nyata terhadap enam lokasi sampling kecuali lokasi pantai Lemahabang. Konsentrasi unsur $\mathrm{Ce}$ tidak ada beda secara nyata terhadap empat lokasi kecuali sedimen Gondang, Lemahabang dan muara Bayuran. Sedangkan konsentrasi unsur $\mathrm{Ca}$ dan Ti beda secara nyata terhadap tujuh lokasi sampling.

\section{KESIMPULAN}

1. Hasil Analisis diperoleh sebaran unsur mayor di seluruh lokasi terdiri dari unsur-unsur Fe dengan konsentrasi berkisar antara $(6,74-11,69) \%$; unsur Ca berkisar antara $(0,74-6,89) \%$ dan unsur Ti berkisar antara $(0,45-1,94) \%$; sedangkan untuk unsur-unsur minor terdiri dari unsur Ba dengan konsentrasi berkisar antara $(451,4-1331,6) \mathrm{mg} / \mathrm{kg}$, unsur Ce berkisar antara $(201,8-427,3) \mathrm{mg} / \mathrm{kg}$, unsur Zr berkisar antara $(192,3-338,5) \mathrm{mg} / \mathrm{kg}$, dan unsur La berkisar antara $(171,7-298,4) \mathrm{mg} / \mathrm{kg}$. Data yang tersusun dapat diakomodasikan data lingkungan terkini dalam rangka mendukung ijin tapak dan Analisis Mengenai Dampak Lingkungan (AMDAL) Pusat Listrik Tenaga Nuklir (PLTN).

2. Hasil nilai akurasi pada penelitian ini lebih besar $90 \%$ kecuali unsur $\mathrm{Ba}$ mempunyai nilai $86,69 \%$. Unsur $\mathrm{Ce}$ yang mempunyai nilai bias kecil $(2,09 \%)$ dan mempunyai nilai akurasi yang tertinggi dibandingkan unsurunsur lainya yaitu sebesar $97,91 \%$.

3. Berdasarkan uji statistik dengan menggunakan metode Anava model desain acak lengkap dengan derajat kepercayaan $\boldsymbol{\alpha}_{0,05}$ menunjukan bahwa sampel sedimen untuk keseluruhan unsur $\mathrm{Fe}, \mathrm{Ca}, \mathrm{Ti}, \mathrm{Ba}, \mathrm{La}, \mathrm{Ce}$ dan Zr dinyatakan bahwa lokasi sampling mempunyai pengaruh perbedaan secara nyata.

\section{DAFTAR PUSTAKA}

1. WARDANA.W.A., Dampak Pencemaran Lingkungan. Andi Offset. Yogyakarta (1995)

2. SUKIRNO. SUDARMADJI., "Pengukuran Radioaktivitas Gamma, Beta dan Identifikasi Radionuklida dalam Sedimen dan Air Sungai". Prosiding PPI_PDIPTN, P3TM-BATAN. Yogyakarta (2001)

3. ANONIM., SK Kepala BAPATEN No 03-P/Ka-BAPETEN/VI-99., Jakarta (1999)

4. ANONIM., SK Kepala BAPATEN No 04-P/Ka-BAPETEN/VI-99., Jakarta (1999)

5. EUGENE.B.P., Introduction to X-Ray Spectrometry Analysis, Plenum Press, New York (1978)

6. DIXIT.R.M. AND DESHPANDE S.S., 1985, X-Ray Florescence Detrmination of Pr, Nd, Gd, Tb, Dy and Y In High Purity Europium Oxide., Bhabha Atomic Research Centre, Bombay India.

7. SUKIRNO., TAFTAZANI.A., SUMINING., "Evaluasi Presisi dan Akurasi Hasil Analisis Fe, $\mathrm{Ti}$ dan $\mathrm{Ce}$ dengan Metode XRF'. Prosiding Seminar Nasional VI., Kimia dalam Lingkungan, Jasakiai., Jogjakarta (2003)

8. DAY,Jr. dan UNDERWOOD. A.L., Analisis Kimia Kuantitatif. Edisi Kelima. Erlangga. Jakarta (1986)

9. SUDJANA, 1990, Desain dan Analisis Eksperimen., Edisi ke III Tarsito, Bandung.(1982) 


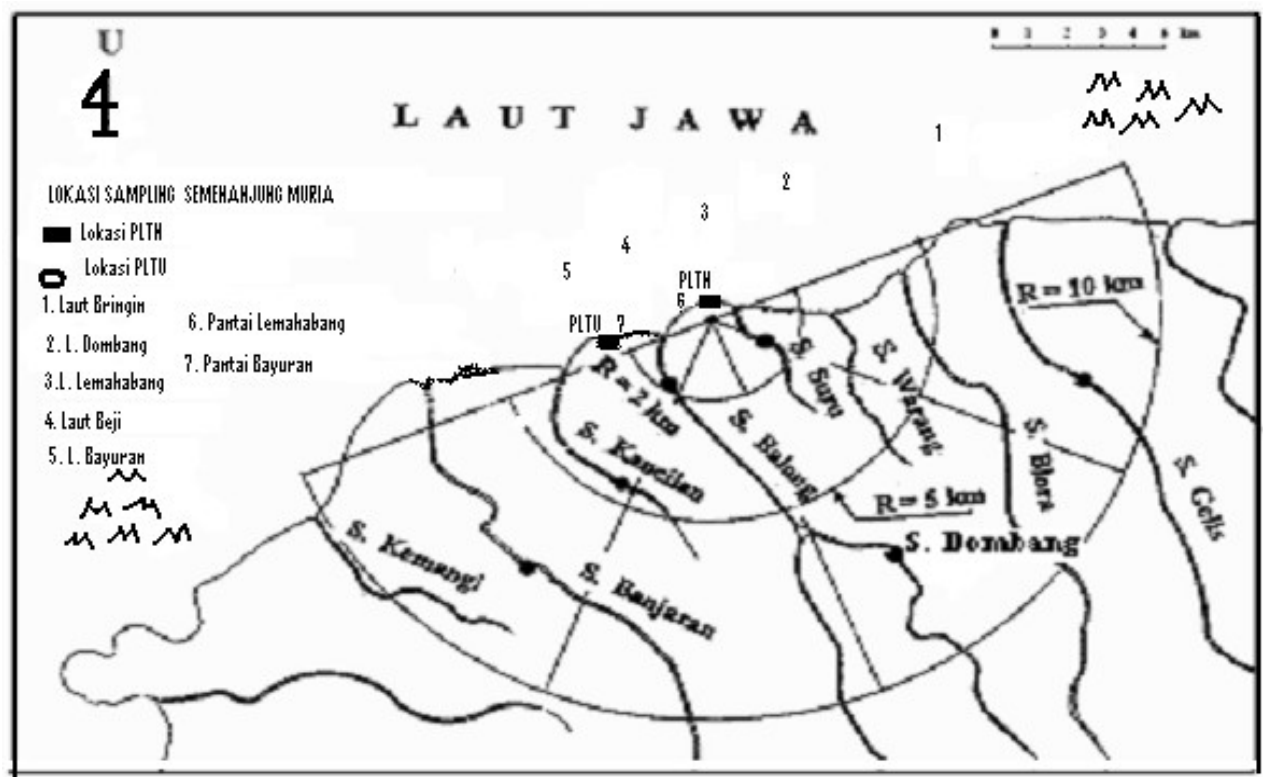

Gambar. 3. Peta lokasi sampling di semenanjung Muria sekitar PLTU dan lokasi rencana pembangunan PLTN 